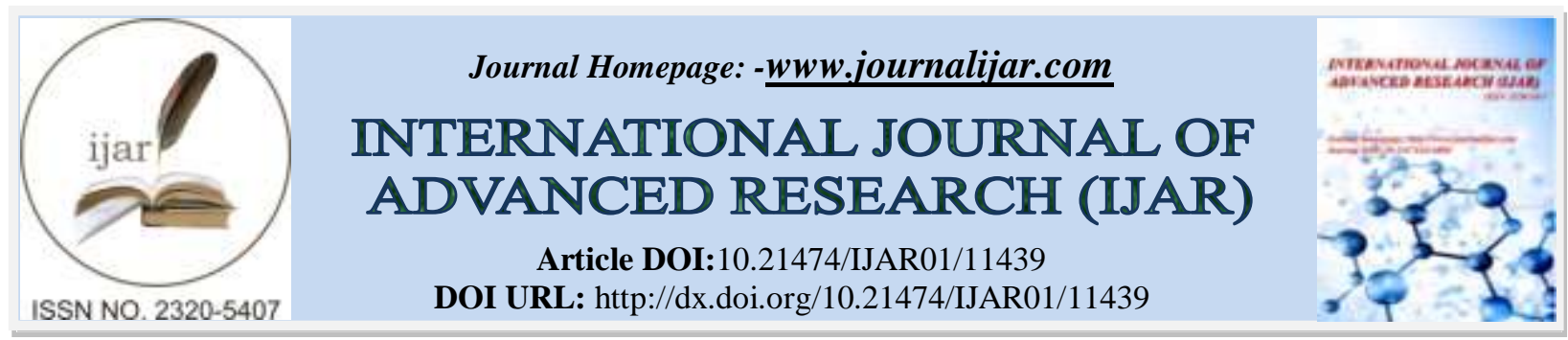

RESEARCH ARTICLE

\title{
PREVALENCE \& CLINICAL SIGNIFICANCE OF NONTUBERCULOUS MYCOBACTERIUM (NTM) SPECIES
}

\author{
Annesha Das \\ Suraksha Genomics (R \& D Division of Suraksha Diagnostics) 12/1, Premises No. 02-0327, DG Block, Action Area \\ 1D, New Town, Kolkata - 700156.
}

\section{Manuscript Info}

…......................

Manuscript History

Received: 31 May 2020

Final Accepted: 30 June 2020

Published: July 2020

Key words:-

Nontuberculous Mycobacterial (Ntm), Mycobacteria Other Than Tuberculosis (Mott)

\section{Abstract}

In developing countries, like India, where tuberculosis is still a huge health challenge, the prevalence of Nontuberculous mycobacterial (NTM) diseases are expected to rise. As themedical conditions (eg. HIV infection), which are related to impair or compromise the immune system, become more widespread, so the opportunistic infections, like Mycobacterial infections will find a dominant role. Among mycobacterial infections, tuberculosis is more common and hence get attention by clinicians, researchers and policy-makers. So, the infections caused by Nontuberculous mycobacteria (NTM) often fall on the category of neglected and ignored cousins. But, the ability of causing infections by different Nontuberculous mycobacterial (NTM) species are also quite high and severity of infections can go to any extent. NTM species can potentially infect any part of the body, starting from CNS to bones. The symptoms also vary from person to person and from one infection type to another. For example, the severity of symptoms ranges from mere cough and weight loss to coughing up of blood (hemoptysis) also in extreme cases can lead to more severe complications, if left untreated or improperly treated. So, along with tubercular Mycobacterium (MTB), our focus should also be laid into the NTM species, as the prevalence and infection causing ability are also very high. So, with regard to the complexity of identification of NTM species, it should be recommended that laboratory diagnosis of NTM diseases can be made centralized by strengthening or setting up quality national and regional level infrastructure.

Copy Right, IJAR, 2020,. All rights reserved.

\section{Introduction:-}

Mycobacterium tuburculosis is certainly one of the most threatening viruses worldwide, as it causes tuberculosis (TB) upon successful infection \& propagation in individuals, specially with mal-nutrition and co-existence of other clinical conditions, known for causing impairment of immune system. Mycobacterium tuberculosis virus becomes detrimental and untreatable, when it gains resistance against one or few standard antibiotics, use to treat tuberculosis. Various levels of resistant strains are known as Totally Drug Resistant (TDR), Multiple Drug Resistant (MDR) and Extensively Drug Resistant (XDR) tuberculosis. Pulmonary tuberculosis is common and henceforth studied well. More recently, other species of mycobacterium causing clinical diseases have been identified in many geographical regions. These NTM species can cause greater disease burden than TB. These organisms are referred 
to by a variety of collective names - atypical mycobacteria or anonymous, mycobacteria other than tuberculosis (MOTT) and nontuberculous mycobacteria (NTM). But, still now these Non-tubercular Mycobacterium (NTM) sp. are often neglected in medical diagnostic field, though NTM infections can occur throughout the body and can be equally detrimental like TB. Though both host and organism characteristics influence the susceptibility and manifestations of infection, lymphadenitis, pulmonary infections and soft tissue and skin infections are the most commonly described attributable human infections (1) caused by NTM species. In this paper, we have tried to give a detailed account of NTM species and infections caused by these species.

\section{Species of Non-tubercular Mycobacterium (NTM):}

Nontuberculous mycobacteria (NTM) is a group of bacteria, that include more than 150 different species, some of which can infect and cause illness in humans and found throughout nature in water and soil. The term nontuberculous mycobacteria refers to all the species in the family of mycobacteria that which may cause human disease but that do not cause tuberculosis (TB) $(2,3)$. NTM do cause pulmonary diseases that resemble tuberculosis (3).

Pulmonary involvement is the most common disease manifestation of NTM and the incidence of NTM is recognized worldwide as well as growing in North America (4, 5). Although over 150 different species of NTM have been described, pulmonary infections are most commonly due to Mycobacterium avium complex (MAC), Mycobacterium kansasii and Mycobacterium abscessus (5).

The most common NTM's that require treatment are M. avium, M. intracellulare, M. abscessus, M. chelonae, M. kansasii, M. fortuitum, M. gordonae, M. massiliense.

Mycobacterium. avium complex: Mycobacterium avium complex (MAC) consists of the two species: M avium and $\mathrm{M}$ intracellulare; because these species are difficult to differentiate, and they are also collectively referred to as Mycobacterium avium-intracellulare (MAI) (6). MAC is ubiquitous in distribution. It has been isolated from the fresh water and salt water worldwide. MAC is the most common cause of infection by nontuberculous mycobacteria (NTM) in patients with AIDS. M. avium causes 95\% of AIDS-related MAC infections (7).

Mycobacterium abscessus: Mycobacterium abscessus is a rapidly growing mycobacterium that is a common water contaminant. It is now considered the prominent Mycobacterium, along with the Mycobacterium avium, that involved in broncho-pulmonary infection in patients with cystic fibrosis or chronic pulmonary disease (8-11). M. abscessus is one of the most resistant organisms to chemotherapeutic agents (12).

Mycobacterium chelonae: Mycobacterium chelonae is a rare pathogen that causes infection among humans. M. chelonae is gram positive bacillus, non-tuberculosis, opportunistic and rapidly growing mycobacteria (RGM) which is exceptionally pathogenic. RGM typically show visible colonies on solid growth media within 1 week (13). M chelonae, along with $\mathrm{M}$ abscessus, are considered the most drug resistant of the NTM group, that leads to difficulty when treating infections these organisms.

Mycobacterium kansasii: Mycobacterium kansasii is an acid-fast bacillus (AFB) bacterium in the Mycobacterium family which is readily recognized based on its characteristic photochromogenicity, can be found virtually anywhere in the environment that produces a yellow pigment when exposed to light. The most common M kansasii infection is a chronic pulmonary infection that resembles pulmonary tuberculosis (14). This infection is the second-most-common nontuberculous opportunistic mycobacterial infection associated with AIDS, that surpassed only by Mycobacterium avium complex (MAC) infection.

Mycobacterium fortuitum: Mycobacterium fortuitum is a nontuberculous mycobacterium (NTM) (Gram-negative bacillus), a grouping which encompasses all the mycobacteria outside of the Mycobacterium tuberculosis complex. It is classified in the Runyon group IV, rapidly growing mycobacteria (15).

Mycobacterium gordonae: Mycobacterium gordonae is ubiquitous and may be found in soil, water. It's a species of Mycobacterium named for Ruth E. Gordon (16). It is classified in Runyon group 2 as a scotochromogenic organism. M. gordonae is the most commonly encountered non-tuberculous mycobacterium in water, with concentrations as high as 1000 colony-forming units per milliliter. 
Mycobacterium massiliense: Mycobacterium massiliense is the rapidly growing Mycobacteria species sharing an identical 16S rRNA sequence with Mycobacterium abscessus.

The table 1 lists clinical conditions that are caused by Nontuberculous mycobacteria (NTM) infection and the species mostly often associated with those conditions.

\section{Pulmonary infections by NTM:}

Pulmonary disease caused by NTM, that may occur as a component of disseminated infection, but often the disease affects specifically the lungs (Table 2). Four main categories of pulmonary disease, which can be nosologically identified. First category is the disease occurs in middle-aged or the older patients, that usually men with a history of lung disease. Second is that, the disease occurs in otherwise apparently healthy persons, although some may have covert and minor immune defects. Third is the disease occurs in children with more severe immune defects or predisposing pulmonary disease, notably severe fungal infection (e.g., semi-invasive or invasive Aspergillus disease) or cystic fibrosis. Fourth is that the disease occurs in very immunosuppressed patients, of which HIV infection is the prevalent cause worldwide. And also, it is very important to emphasize that patients with NTM diseases do not need to be isolated because of the noncommunicableness of these conditions.

\section{Extra-Pulmonary infections by NTM:}

Tubercular infections involve the pulmonary system is about $90 \%$; the rest involve the lymph nodes, soft tissues, skin and bones. Less frequently reported are central nervous system disease, keratitis, and otitis media $(17, \mathbf{1 8})$. Common type of extra-pulmonary infections are the following:

\section{Osteoarticular Infections:}

NTM infections involving the musculoskeletal system are not common. But, when these infection do occur, these have been often implicated in chronic granulomatous infections involving bursae, tendon sheaths, bones and joints. Usually these types of infection are acquired either by direct inoculation of the pathogen from an external environmental source or a contiguous infection due to some surgical procedures, needle injections, injuries. Mostly the affected patients are immunocompetent, but some of the mycobacterial species, such as M. hemophilum and M. chelonae are almost entirely recovered from patients with serious underlying diseases (blood disorders like thalassaemia, HIV infection, immunosuppressive therapy etc.) (19).

\section{Lymphadenitis:}

Localized lymphadenitis mostly affects children. Peak incidence occurs at age of 1-5 years (20). The route of infection is hypothesized to be by way of the lymphatic vessels, that drain the mouth and pharynx. Most frequently isolated species is Mycobacterium avium complex (MAC), followed by M. malmoense, M. scrofulaceum, and M. hemophilum (21).

\section{Skin and Soft Tissue Infections:}

Skin and soft tissue infections that usually occur after surgery, traumatic injury or cosmetic procedures, which may expose a wound to water, soil or medical devices occasionally contaminated with environmental mycobacteria. Although the epidemiology and clinical presentations of NTM responsible for skin and soft tissue infections differ, some species (MAC, M. xenopi, M. kansasii and M. marinum) have been reported worldwide, whereas others (M. ulcerans) have limited geographic distribution.

Cutaneous MAC diseases may occur by direct inoculation (surgery, trauma, injection) and it is characterized by skin lesions such as ulceration, abscess with sinus formation or erythematous plaque with a yellow crusted base. The lesions are indolent, with little or no lymph node reaction or systemic symptoms.

\section{Laboratory Investigations for NTM:}

All the currently described mycobacterial species, there are $\approx 60 \%$ have caused human diseases. For that reason, modern techniques for conventional microbiological diagnosis, faster culture, identification, and drug susceptibility testing, histopathological diagnosis, molecular identification of NTM species are urgently needed in mycobacteriology laboratories $(22,23)$. In addition to the collection of high-quality specimens, timely diagnosis of the NTM disease requires regular communication of clinical suspicion to the laboratory staff because optimal recover of some fastidious species requires additional tasks. Routine techniques mostly include microscopy and culture; the latter should be performed by using of both solid and liquid media incubated at different temperatures 
(22). Although optimal recovery for most clinically relevant mycobacteria is obtained at $35 \mathrm{C}^{\circ}-37 \mathrm{C}^{\circ}$, some species (M. marinum, M. hemophilum, M. ulcerans and some species of RGM) require a lower incubation temperature to grow. That is why, all clinical specimens that may harbor the above species (synovial fluid, skin and bone) that should be cultured at $28 \mathrm{C}^{\circ}-30 \mathrm{C}^{\circ}$ and at $35 \mathrm{C}^{\circ}-37 \mathrm{C}^{\circ}$. Use of the conventional biochemical and phenotypic tests for the identification of NTM is currently discouraged; more specific and rapid methods are favored, including highperformance liquid chromatography (HPLC) analysis of the mycolic acids and commercial molecular assays. That may use either in solid-format reversehybridization assays (line probe assays) or solution hybridization (GenProbe Inc., San Diego, CA, Accuprobe, USA) (22). Both the techniques are very specific, but the latter (in which amplification precedes hybridization) is more sensitive, enabling identification in the early stage of bacterial growth. Gene (16S rDNA) sequencing is required for those species that cannot be identified by the above systems (22). Careful strategies should be recommended for using 16S rDNA sequence analysis databases because the public databases may have wrong sequences and commercial ones tend to be underdeveloped, outdated $(24,25)$ and infrastructure wise impracticable in diagnostic laboratories. Newer strategies to identify Tuberculosis and NTMs simultaneously by Real Time PCR method are more viable in diagnostic settings and clinically more useful.

\section{Therapies against NTMs:}

Recommendations for treating the NTM pulmonary disease are given in Table 3. Patients undergoing therapy for the NTM pulmonary disease, that require frequent follow-ups to evaluate objective and symptomatic response to therapy and medication toxicity, and to collect specimens for AFB analysis. Treatment recommendations for selected Nontuberculous Mycobacteria causing the lung and disseminated disease are summarized in Table 3.

\section{Discussion:-}

NTM lung disease is a common term for a group of disorders characterized by exposure to specific bacterial strains, known as mycobacteria. These bacteria are found in the soil and water are common throughout the environment as a whole. They usually do not cause any illness. The term 'non-tuberculous' is generally used to differentiate these disorders from the mycobacterium infections, which cause tuberculosis (i.e. mycobacterium tuberculosis complex). These disorders exclude Mycobacterium leprae, the mycobacterium responsible for causing leprosy.

In NTM disorders, the disease course and the severity of infection can vary from person to person. The most common symptoms include fatigue, a persistent cough, night sweats, weight loss and coughing up of blood (hemoptysis). Occasionally symptoms may include shortness of breath (dyspnea). Less often, NTM infection can also cause inflammation of the lymph nodes (lymphadenitis) and skin or soft tissue infection. Most evidence indicates that these infections are not generally transmitted from one person to another, but mostly are acquired from the environment. That is why, keeping a track about the prevalence and infection spectrum is very much necessary part of health program. NTM lung disease most commonly affects persons with an underlying lung disease such as cystic fibrosis, chronic obstructive pulmonary disease (COPD), bronchiectasis primary ciliary dyskinesia and alpha1 -antitrypsin disease. But individuals with no previous history of lung disease can also be affected. Less severe infections always may not require treatment. In some cases, the infection can become chronic requiring continuous ongoing treatment.

Nontuberculous mycobacterial species are ubiquitous in the environment, especially in tuberculosis (TB) prone area, like most of the underdeveloped and developing country. These NTMs have the potential to colonize and cause serious infection in human. As newer molecular techniques like RT-PCR, 16s-rRNA sequencing etc. are coming up, the number of species are also going on increasing and clinical presentations are being documented and described from different parts of the world. Extensive scientific progress has been made towards the understanding of the underlying predisposing factors, for MTB and NTM infections. It is frequently seen that, diseases caused by nontuberculous mycobacteria is often associated with various forms of immunosuppression, specially HIV infection, whereas mild forms of immune defects have been seen in some patients who, apart from their nontuberculous mycobacterial disease, looks to be healthy on initial examination. Newer molecular techniques, like RT-PCR based assays or species indentification of 16s-rRNA sequencing have shown their usefulness for the identification of most of the mycobacterial species. Probes are widely used in clinical laboratories for the identification of the common mycobacterial species. Because automated capillary based DNA sequencing and the programs for analyzing sequence data have become technically widespread, polymerase chain reaction-based DNA sequencing technique is now used in many mycobacterial reference laboratories in many part of the world, as a routine method for exact species identification. 


\section{Conclusion:-}

As MTB related tuberculosis is most common, so all our focus are concentrated diagnosis, treatment and identification of Mycobactrial tubercular species. But, as NTMs are also becoming prevalent, so our paradigm should also to be shifted towards proper identification, laboratory diagnosis of Nontubercular mycobacterial species to ultimately contribute towards better treatment of the NTM infections, as it has also proved to be detrimental, if not properly and timely treated. Diagnosis of infection due to nontuberculous mycobacteria is challenging, as it must be distinguished from contamination or colonization by other tuberculous mycobacterial species. Molecular methods, like RT-PCR and 16s-rRNA sequencing can offer many advantages over conventional methods of identification. The results obtained by molecular studies are rapid, reliable and reproducible. Even from mixed or contaminated cultures, accurate result can be obtained by using molecular methods. The DNA microarray based point of care techniques holds great promise for the future because it will be easy to perform, it can be readily automated, and it allows the identification of a large number of mycobacterial species in one reaction.

\section{Tables:}

Table 1: Major clinical syndromes that associated with Nontuberculous Mycobacterial infections

Table 2: Clinical settings for Nontuberculous Mycobacterial lung disease

Table 3: Treatment recommendations for selected Nontuberculous Mycobacteria causing the lung and disseminated disease

Table 1:- Major clinical syndromes that associated with Nontuberculous Mycobacterial infections.

\begin{tabular}{|c|c|c|}
\hline CONDITION & COMMON CAUSES & LESS COMMON CAUSES \\
\hline $\begin{array}{llll}\text { Lung } & \text { (pulmonary) } & \text { disease } & \text { (in } \\
\text { adults) } & & & \end{array}$ & $\begin{array}{lcc}\text { M. } & \text { avium complex } \\
\text { kansasii, } M . \text { abscessus }\end{array}$ & 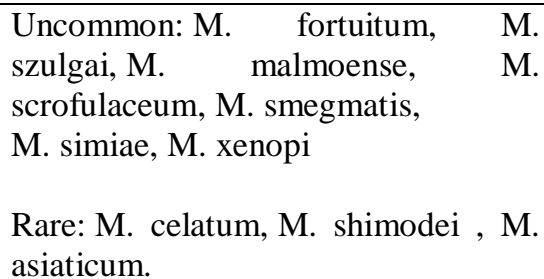 \\
\hline $\begin{array}{l}\text { Cervical lymphadenitis (infection of } \\
\text { the lymph nodes in the neck), (in } \\
\text { children) }\end{array}$ & M. intracellulare, M. avium & $\begin{array}{l}\text { M. scrofulaceum, M. abscessus, M. } \\
\text { malmoense, M. fortuitum. }\end{array}$ \\
\hline Skin and soft tissue disease & $\begin{array}{l}\text { M. chelonae, M. abscessus, M. } \\
\text { fortuitum, M. marinum }\end{array}$ & $\begin{array}{l}\text { M. kansasi, M. smegmatis, M. } \\
\text { haemophilum, M. ulcerans. }\end{array}$ \\
\hline $\begin{array}{l}\text { Skeletal (bones, joints, tendons) } \\
\text { disease }\end{array}$ & $\begin{array}{l}\text { M. marinum, M. avium complex, } \\
\text { M. fortuitum group, M. abscessus, } \\
\text { M. kansasii, M. chelonae }\end{array}$ & $\begin{array}{l}\text { M. haemophilum, M. smegmatis, M. } \\
\text { terrae-nonchromogenicum complex, } \\
\text { M. scrofulaceum. }\end{array}$ \\
\hline Catheter-related infections & $\begin{array}{l}\text { M. abscessus, M. fortuitum, M. } \\
\text { chelonae. }\end{array}$ & M. mucogenicum. \\
\hline \multirow[t]{2}{*}{$\begin{array}{l}\text { Disseminated infection (especially } \\
\text { in people who are HIV-positive or } \\
\text { have weakened immune systems ) }\end{array}$} & $\begin{array}{l}\text { HIV-seropositive host: M. kansasii, } \\
\text { M. avium. }\end{array}$ & $\begin{array}{l}\text { M. kansasii, M. haemophilum, M. } \\
\text { marinu, M. fortuitum. }\end{array}$ \\
\hline & $\begin{array}{l}\text { HIV-seronegative host: } \\
\text { chelonae, M. abscessus. }\end{array}$ & \\
\hline
\end{tabular}

Table 2:- Clinical settings for Nontuberculous Mycobacterial lung disease.

\begin{tabular}{|c|c|c|c|}
\hline Radiographic Disease & Usual Pathogen & Setting & Rare Pathogen \\
\hline $\begin{array}{l}\text { RML, lingular nodular } \\
\text { bronchiectasis }\end{array}$ & $\begin{array}{l}\text { M. abscessus, } \\
\text { avium complex, }\end{array}$ & $\begin{array}{l}\text { Female nonsmokers, usually } \\
\text { older than } 60 \mathrm{yr}\end{array}$ & M. kansasii \\
\hline $\begin{array}{l}\text { Reticulonodular or alveolar } \\
\text { lower lobe disease }\end{array}$ & M. fortuitum & $\begin{array}{l}\text { Chronic vomiting secondary } \\
\text { to GI disease, Achalasia, } \\
\text { exogenous lipoid } \\
\text { pneumonia (mineral oil } \\
\text { aspiration. etc.) }\end{array}$ & $\begin{array}{l}\text { M. avium complex, M. } \\
\text { smegmatis, } \\
\text { abscessus }\end{array}$ \\
\hline Upper lobe cavitary & $\begin{array}{l}\text { M. kansasii, } \\
\text { avium complex, }\end{array}$ & $\begin{array}{l}\text { Male smokers, often } \\
\text { abusing alcohol, usually in }\end{array}$ & \\
\hline
\end{tabular}




\begin{tabular}{|l|l|l|l|}
\hline & \multicolumn{1}{|c|}{ abscessus, M. } & $\begin{array}{l}\text { their early 50s } \\
\text { fibroscents with cystic }\end{array}$ & \\
\hline fot well established & $\begin{array}{l}\text { M. } \\
\text { avium complex }\end{array}$ & $\begin{array}{l}\text { HIV-positive hosts, patients } \\
\text { with preexisting } \\
\text { bronchiectasis, others }\end{array}$ & \\
\hline Reticulonodular disease & M. avium complex & $\begin{array}{l}\text { Prior granulomatous disease } \\
\text { (usually tuberculosis) with } \\
\text { bronchiectasis }\end{array}$ & \\
\hline $\begin{array}{l}\text { Localized alveolar, cavitary } \\
\text { disease }\end{array}$ & \begin{tabular}{l} 
M. avium complex, Msessus \\
\hline
\end{tabular}
\end{tabular}

Table 3:- Treatment recommendations for selected Nontuberculous Mycobacteria causing the lung and disseminated disease.

\begin{tabular}{|c|c|c|c|}
\hline NTM & Suggested Drug Regimen & Duration of Therapy & Comments \\
\hline $\begin{array}{l}\text { M. kansasii } \\
\text { (rifampin } \\
\text { susceptible in vitro) }\end{array}$ & $\begin{array}{l}300 \mathrm{mg} / \text { dayplus ethambutol, } \\
\text { Rifampin, } 600 \mathrm{mg} / \text { day plus INH, } \\
25 \mathrm{mg} / \mathrm{kg} / \mathrm{day} \text { for } 2 \text { month and } \\
\text { then } 15 \mathrm{mg} / \mathrm{kg} / \text { day }\end{array}$ & $\begin{array}{l}18 \text { month and } 12 \text { month } \\
\text { of sputum AFB culture } \\
\text { negativity for pulmonary } \\
\text { disease or lifetime } \\
\text { therapy for disseminated } \\
\text { disease unless immune } \\
\text { status restored. }\end{array}$ & $\begin{array}{l}500-1000 \mathrm{mg} \\
\text { MWF or clarithromycin, } \\
\text { Add streptomycin, } 1 \mathrm{~g} / \text { day } \\
\text { initially }(2-3 \mathrm{mo}) \text { for } \\
\text { advanced disease; treatment } \\
\text { success with this regimen } \\
\text { dependent on in vitro } \\
\text { rifampin susceptibility; } \\
\text { PZA not effective. }\end{array}$ \\
\hline $\begin{array}{ll}\text { M. } & \text { kansasii } \\
\text { (rifampin } & \text { resistant } \\
\text { in vitro) } & \end{array}$ & $\begin{array}{l}0.5 \mathrm{~g} \text { q12 h plus ethambutol, } \\
25 \mathrm{mg} / \mathrm{kg} / \text { day for } 2 \mathrm{mo} \text { and then } \\
15 \mathrm{mg} / \mathrm{kg} \text { /dayplus INH, } \\
\text { Clarithromycin, } 900 \mathrm{mg} / \text { day plus } \\
\text { sulfamethoxazole, } 1.0 \mathrm{~g} \\
\text { streptomycin, 500-1000 mg IM } \\
\text { MWF (initial 2-3 month) }\end{array}$ & $\begin{array}{l}12 \text { month of sputum AFB } \\
\text { culture negativity for the } \\
\text { pulmonary disease or } \\
\text { lifetime therapy for the } \\
\text { disseminated disease, } \\
\text { unless immune status } \\
\text { restored. }\end{array}$ & $\begin{array}{l}\text { In vitro rifampin resistance } \\
\text { occurs as consequence of } \\
\text { treatment failure } \\
\text { (noncompliance) for } \\
\text { rifampin-susceptible M. } \\
\text { kansasii lung disease; } \\
\text { rifabutin, } 150 \mathrm{mg} / \text { day can } \\
\text { be used with indinavir }\end{array}$ \\
\hline MAI & $\begin{array}{l}\text { Clarithromycin, } \\
1 \text { g or azithromycin, } \\
\text { MWF plus rifabutin, } \\
300 \mathrm{mg} \text { or rifampin, } \\
\text { MWF plus ethambutol, } 25 \mathrm{mg} / \mathrm{kg} \\
\text { MWF }\end{array}$ & $\begin{array}{l}12 \text { month of sputum AFB } \\
\text { culture negativity for the } \\
\text { pulmonary disease, or } \\
\text { lifetime therapy for the } \\
\text { disseminated disease, } \\
\text { unless immune status } \\
\text { restored }\end{array}$ & $\begin{array}{lrr}\begin{array}{l}\text { Clarithromycin } \\
\text { azithromycin }\end{array} & \text { or } \\
\text { monotherapy; } & \text { as } \\
\text { resection if } & \begin{array}{r}\text { surgical } \\
\text { pulmonited }\end{array} \\
\text { streptomycin for } & 2-3 \mathrm{mo} \text { disease; } \\
500-1000 \mathrm{mg} & \mathrm{IM} \\
\text { MWF or amikacin, } 400 \mathrm{mg} \\
\text { IV daily for severe disease; } \\
\text { rifampin contraindicated } \\
\text { with protease inhibitors }\end{array}$ \\
\hline M. abscessus & $\begin{array}{l}\text { Clarithromycin, } \\
1 \mathrm{~g} / \text { day or azithromycin, } 500 \mathrm{mg} \\
\text { MWF } \pm \text { cefoxitin, imipenem, } \\
\text { amikacin }\end{array}$ & $\begin{array}{l}12 \text { month of sputum AFB } \\
\text { culture negativity }\end{array}$ & $\begin{array}{l}\text { No drug regimen of proven } \\
\text { efficacy; surgical resection } \\
\text { of the limited pulmonary } \\
\text { disease most effective } \\
\text { therapy; } \\
\begin{array}{l}\text { antituberculosis drugs not } \\
\text { useful }\end{array}\end{array}$ \\
\hline M. chelonae & Clarithromycin, $1 \mathrm{~g} /$ day & 6 month & $\begin{array}{l}\text { Macrolide monotherapy } \\
\text { effective }\end{array}$ \\
\hline M. fortuitum & $\begin{array}{l}\text { Two agents, including } \\
800 \mathrm{mg} / \text { dayor ciprofloxacin, } \\
\text { ofloxacin, } 1500 \mathrm{mg} / \text { day, } \\
\text { doxycycline } \\
\text { sulfamethoxazole, }\end{array}$ & 6 month & $\begin{array}{l}\text { Therapy based on the in } \\
\text { vitro antibiotic } \\
\text { susceptibility; only } 50 \% \text { of } \\
\text { M. fortuitum isolates } \\
\text { susceptible to }\end{array}$ \\
\hline
\end{tabular}




\begin{tabular}{|l|l|l|}
\hline & clarithromycin, $0.5 \mathrm{~g}$ & $\begin{array}{l}\text { clarithromycin; For the } \\
\text { severe disease, amikacin, } \\
\text { ang mg/day IV or cefoxitin, } \\
12 \mathrm{~g} / \text { day IV, until favorable } \\
\text { clinical response; first-line } \\
\text { anti-tuberculosis drugs are } \\
\text { not useful. }\end{array}$ \\
\hline
\end{tabular}

\section{References:-}

1. Chan ED, Iseman MD. Underlying host risk factors for nontuberculous mycobacterial lung disease. Semin Respir Crit Care Med 2013;34:110-23.

2. Atypical Mycobacteria at the US National Library of Medicine Medical Subject Headings (MeSH).

3. American Thoracic Society (1997). "Diagnosis and treatment of disease caused by nontuberculous mycobacteria. This official statement of the American Thoracic Society was approved by the Board of Directors, March 1997. Medical Section of the American Lung Association". American Journal of Respiratory and Critical Care Medicine 156 (2 Pt 2): S1-25.doi:10.1164/ajrccm.156.2.atsstatement. PMID 9279284.

4. Nontuberculous mycobacterial pulmonary infections. Margaret M. Johnson and John A. Odell. J Thorac Dis. 2014 Mar; 6(3): 210-220. doi: 10.3978/j.issn.2072-1439.2013.12.24.

5. Highlight on Advances in Nontuberculous Mycobacterial Disease in North America. Mehdi Mirsaeidi, Maham Farshidpour, Mary Beth Allen, Golnaz Ebrahimi and Joseph O. Falkinham. BioMed Research International Volume 2014 (2014), Article ID 919474, 10 pages. http://dx.doi.org/10.1155/2014/919474.

6. "Disease Listing, Mycobacterium avium Complex". CDC Bacterial, Mycotic Diseases. Retrieved 2010-11-04.

7. Mycobacterium avium complex in patients with HIV infection in the era of highly active antiretroviral therapy. Karakousis PC, Moore RD, Chaisson RE; Lancet Infect Dis. 2004 Sep;4(9):557-65.

8. Chronic Mycobacterium abscessus infection and lung function decline in cystic fibrosis. Esther CR Jr, Esserman DA, Gilligan P, Kerr A, Noone PG;

9. J Cyst Fibros. 2010 Mar;9(2):117-23. doi: 10.1016/j.jcf.2009.12.001. Epub 2010 Jan 13.

10. Clinical features of pulmonary disease caused by rapidly growing mycobacteria. An analysis of 154 patients. Griffith DE, Girard WM, Wallace RJ Jr. Am Rev Respir Dis. 1993 May;147(5):1271-8.

11. Mycobacterium abscessus and children with cystic fibrosis. Sermet-Gaudelus I, Le Bourgeois M, PierreAudigier C, Offredo C, Guillemot D, Halley S, Akoua-Koffi C, Vincent V, Sivadon-Tardy V, Ferroni A, Berche P, Scheinmann P, Lenoir G, Gaillard JL. Emerg Infect Dis. 2003 Dec;9(12):1587-91.

12. Non-tuberculous mycobacteria in children with cystic fibrosis: isolation, prevalence, andpredictors. Radhakrishnan DK, Yau Y, Corey M, Richardson S, Chedore P, Jamieson F, Dell SD. Pediatr Pulmonol. 2009 Nov;44(11):1100-6. doi: 10.1002/ppul.21106.

13. Clinical and taxonomic status of pathogenic nonpigmented or late pigmenting rapidlygrowing mycobacteria. Brown-Elliott BA, Wallace RJ Jr. Clin Microbiol Rev. 2002 Oct;15(4):716-46.

14. Clinical and taxonomic status of pathogenic nonpigmented or late-pigmenting rapidly growing mycobacteria. Brown-Elliott BA, Wallace RJ Jr. Clin Microbiol Rev. 2002 Oct. 15(4):716-46.

15. Sherris Medical Microbiology (4th ed.). Ryan KJ; Ray CG, eds. (2004). McGraw Hill. ISBN 0-8385-8529-9.

16. Complete Genome Sequence of Mycobacterium fortuitum subsp. fortuitum Type Strain DSM46621. Ho YS, Adroub SA, Aleisa F, Mahmood H, Othoum G, Rashid F, et al. J Bacteriol. 2012 Nov. 194(22):6337-8.

17. Mycobacterium gordonae at eMedicine .

18. Falkinham JO Epidemiology of infection by nontuberculosis mycobacteria. Clin Microbiol Rev 1996;9:177215.

19. 2. Griffith DE, Aksamit T, Brown-Elliott BA, Catanzaro A, Daley C, Gordin F An official ATS/IDSA statement: diagnosis, treatment, and prevention of nontuberculous mycobacterial disease. Am J Respir Crit Care Med 2007;175:367-416 10.1164/rccm.200604-571ST.

20. 4. Dobos KM, Quinn FD, Ashford DA, Horsburgh CR, King CH Emergence of a unique group of necrotizing mycobacterial diseases. Emerg Infect Dis 1999;5:367-78 10.3201/eid0503.990307.

21. 6. Lai KK, Stottmeier KD, Sherman IH, McCabe WR Mycobacterial cervical lymphadenopathy. Relation of etiologic agent to age. JAMA 1984;251:1286-8 10.1001/jama.251.10.1286.

22. 7. Lindeboom JA, Prins JM, Bruijnesteijn van Coppenraet ES, Lindeboom R, Kuijper EJ Cervicofacial lymphadenitis in children caused by Mycobacterium haemophilum. Clin Infect Dis 2005;41:1569-75 10.1086/497834. 
23. Clinical and Laboratory Standards Institute. Laboratory detection and identification of mycobacteria: approved guideline. CLSI document M48-A. Wayne (PA): The Institute; 2008.

24. National Committee for Clinical Laboratory Standards. Susceptibility testing of mycobacteria, nocardia, and other aerobic actinomycetes. Approved standard M24-A. Wayne (PA): The Committee; 2003.

25. Identification of Mycobacterium spp. by using a commercial 16S ribosomal DNA sequencing kit and additional sequencing libraries. Cloud JL, Neal H, Rosenberry R, Turenne CY, Jama M, Hillyard DR, et al. J Clin Microbiol. 2002;40:400-6. DOI: 10.1128/ JCM.40.2.400-406.2002.

26. Necessity of qualitycontrolled 16S rRNA gene sequence databases: identifying nontuberculous Mycobacterium species. Turenne CY, Tschetter L, Wolfe J, Kabani A. J Clin Microbiol. 2001;39:3637- 48. DOI: 10.1128/JCM.39.10.3638-3648.2001. 